\title{
PENERAPAN MODEL PEMBELAJARAN PETA PIKIRAN (MIND MAPPING) UNTUK MENINGKATKAN HASIL BELAJAR IPA PADA PESERTA DIDIK
}

\author{
M. Ramli \\ Astriani \\ Universitas MuhammadiyahPalangkaraya
}

\begin{abstract}
Abstrak: Penelitian ini bertujuan untuk : (1) mengetahui aktivitas peserta didik pada saat pembelajaran IPA dengan menggunakan model pembelajaran peta pikiran (Mind Mapping), (2) mengetahui peningkatan hasil belajar IPA dengan menggunakan model pembelajaran peta pikiran (Mind Mapping). Penelitian ini dilakukan pada minggu ke-4 bulan Mei 2014 yang berlokasi di MIS Hidayatul Insan, Jl Sulawesi no 67 Palangka Raya. Jenis penelitian ini adalah Penelitian Tindakan Kelas ( PTK ) dengan subjek penelitian seluruh peserta didik kelas IV MIS Hidayatul Insan Palangka Raya yang berjumlah 36 peserta didik. Teknik pengumpulan data dalam penelitian ini menggunakan tes dan observasi. Analisis data menggunakan analisis data kualitatif dan kuantitatif. Indikator keberhasilan dalam penelitian ini adalah apabila ketuntasan aktivitas belajar peserta didik secara klasikal mencapai skor minimal 3, hasil belajar dengan kriteria ketuntasan minimal 60 dengan ketuntasan belajar secara klasikal mencapai nilai minimal 85\%. Hasil penelitian ini menunjukkan bahwa : (1) penggunaan model pembelajaran peta pikiran ( mind mapping) dapat meningkatkan aktivitas peserta didik yang ditunjukkan dengan perolehan skor hasil pengamatan di atas 3, (2) pengunaan model pembelajaran peta pikiran ( mind mapping) dapat meningkatkan hasil belajar peserta didik yang ditunjukkan dengan perolehan nilai rata-rata 60,69 pada siklus I meningkat menjadi 74,3 pada siklus II. Ketuntasan belajar secara klasikal juga mengalami peningkatan dengan nilai 63\% pada siklus I meningkat menjadi $88 \%$ pada siklus II.
\end{abstract}

Kata Kunci: Model, Pembelajaran, Peta Pikiran, IPA.

\section{PENDAHULUAN}

Pendidikan adalah proses pengubahan sikap dan perilaku seseorang atau kelompok orang dalam usaha mendewasakan manusia melalui upaya pengajaran dan penelitian. Pendidikan pada hakekatnya adalah salah satu usaha untuk mencerdaskan kehidupan bangsa agar menjadi manusia seutuhnya yang berjiwa Pancasila sesuai dengan ketentuan yang di anut dalam pembukaan UUD 1945. Hal ini sesuai dengan kedudukan dan fungsi dari Pancasila dan UUD 1945 yang sering disebut Pancasila sebagai Landasan Idiil Pendidikan Nasional, sedang UUD 1945 disebut sebagai Landasan Konstitusional Pendidikan Nasional.
Hakekatnya

pendidikan berlangsung sepanjang hayat. Dalam konteks ini, pendidikan dapat berlangsung di dalam berbagai lingkungan, yaitu di dalam pendidikan keluarga, di dalam lingkungan pendidikan formal (sekolah), dan di dalam lingkungan masyarakat. Pendidikan dasar (Sekolah Dasar) merupakan jenjang pendidikan sekolah yang melandasi jenjang pendidikan menengah.

Dalam hal ini peserta didik salah satu komponen yang terkait dalam pencapaian tujuan pendidikan $:-1$ Dasar, tentunya diharapkan $n \quad \begin{array}{lll}1 & \text { i }\end{array}$ kemampuan memberdayakan diri, membentuk kualitas diri dan berlomba- 
lomba untuk berpacu meraih prestasi yang lebih baik.

$$
\text { Produk pendidikan yang }
$$

berkualitas tidak terlepas dari peran pendidik dalam proses pembelajaran. Guru dituntut mampu menciptakan situasi pembelajaran yang aktif, inovatif, kreatif, dan menyenangkan (PAIKEM) dalam proses kegiatan pembelajaran, khususnya pembelajaran IPA. IPA menjadi sangat penting seiring dengan perkembangan ilmu pengetahuan dan teknologi yang semakin meningkat, sebagai salah satu ilmu yang memiliki nilai esensial yang dapat diterapkan dalam berbagai bidang kehidupan. Pada hakikatnya peserta didik merupakan salah satu komponen dalam pencapaian tujuan pendidikan, tentunya diharapkan agar hasil belajar IPA peserta didik dapat meningkat. Begitu pula pendidik, hendaknya dikombinasikan dengan model-model yang lain secara bervariasi sehingga tidak berfokus pada metode ceramah saja. Beberapa model pembelajaran yang digunakan untuk meningkatkan hasil belajar peserta didik adalah dengan menggunakan model pembelajaran peta pikiran (mind mapping).

Pembelajaran IPA merupakan salah satu pembelajaran yang memerlukan inovasi dan kreatifitas, maka dengan menggunakan model pembelajaran peta pikiran (mind mapping) proses pembelajaran IPA akan menjadi lebih baik serta tujuan pembelajaran dapat tercapai secara optimal sebagai penunjang dalam meningkatkan hasil belajar IPA dengan menggunakan model pembelajaran peta pikiran (mind mapping).

Berdasarkan hasil observasi di MIS

Hidayatul Insan, pada proses pembelajaran IPA terlihat peserta didik tidak bersemangat terhadap pelajaran yang diajarkan oleh pendidik, sehingga suasana saat belajar kurang menyenangkan dan tidak efektif. Hal ini diidentifikasikan dari hasil belajar yang belum memenuhi kriteria ketuntasan minimum (KKM). Pembelajaran IPA yang menggunakan metode ceramah saja cenderung mengakibatkan kebosanan karena tidak ada variasi dalam belajar dan hasil belajar IPA kelas IV memperoleh nilai di bawah kriteria ketuntasan minimal. Hal ini terlihat dari hasil belajar IPA peserta didik kelas IV MIS Hidayatul Insan yang masih belum mencapai nilai standar kriteria ketuntasan minimal (KKM) yaitu 60. Diketahui bahwa dalam proses pembelajaran IPA pada kelas IV nilai yang diperoleh peserta didik masih ada yang dibawah nilai 60. Dimana jumlah peserta didik 36 orang sekitar $55,6 \%$ yaitu 20 orang peserta didik masih di bawah nilai Kriteria Ketuntasan Minimal (KKM) dan sekitar $44,4 \%$ yaitu 16 orang peserta didik yang mencapai Kriteria Ketuntasan Minimal (KKM).

Dari fenomena diatas dapat disimpulkan bahwa rendahnya hasil belajar IPA peserta didik karena kurangnya variasi model pembelajaran, maka hendaknya guru mampu memilih dan mampu menerapkan model pembelajaran yang mampu merangsang siswa lebih aktif dalam belajar IPA, yaitu dengan menggunakan model pembelajaran peta pikiran (mind mapping).

Menurut Sudjana (2010:22) "Hasil belajar adalah kemampuan-kemampuan yang dimiliki peserta didik setelah ia menerima pengalaman belajar". Menurut Dimyati dan Mudjiono (2009:3) "Hasil belajar merupakan hasil dari suatu interaksi tindak belajar dan tindak mengajar".

Sedangkan menurut Arikunto (Slamet Widodo, 2014 : 15) "hasil belajar peserta didik dapat dilihat dari hasil tes prestasi belajar yang dicapai peserta didik setelah mengikuti kegiatan belajar".

Berdasarkan beberapa pendapat di atas, dapat disimpulkan bahwa hasil belajar yang diperoleh peserta didik dengan melalui proses kegiatan pembelajaran yang sudah dirancang guru sehingga setelah kegiatan belajar mengajar peserta didik memperoleh pengalamanpengalaman belajar dan memiliki tingkat penguasaan dalam materi pelajaran untuk 
mengetahui tinggi, sedang, dan rendahnya hasil belajar.

Setiap proses belajar yang dilaksanakan oleh peserta didik akan menghasilkan hasil belajar. Di dalam proses pembelajaran, guru sebagai pengajar sekaligus pendidik memegang peranan dan tanggung jawab yang besar dalam rangka membantu meningkatkan keberhasilan peserta didik dipengaruhi oleh kualitas pengajaran dan faktor intern dari peserta didik itu sendiri.

Dalam setiap mengikuti proses pembelajaran di sekolah sudah pasti setiap peserta didik mengharapkan mendapatkan hasil belajar yang baik, sebab hasil belajar yang baik dapat membantu peserta didik dalam mencapai tujuannya. Hasil belajar yang baik hanya dicapai melalui proses belajar yang baik pula. Jika proses belajar tidak optimal sangat sulit diharapkan terjad inya hasil belajar yang baik.

Dengan demikian hasil belajar adalah sesuatu yang dicapai atau diperoleh siswa berkat adanya usaha atau pikiran yang mana hal tersebut dinyatakan dalam bentuk penguasaan, pengetahuan dan kecakapan dasar yang terdapat dalam berbagai aspek kehidupan sehingga nampak pada diri individu penggunaan penilaian terhadap sikap, pengetahuan dan kecakapan dasar yang terdapat dalam berbagai aspek kehidupan sehingga nampak pada diri individu perubahan tingkah laku secara kuantitatif.

Model pembelajaran pada dasarnya merupakan bentuk pembelajaran yang tergambar dari awal sampai akhir yang disajikan secara khas oleh guru. Dengan kata lain, model pembelajaran merupakan bungkus atau bingkai dari penerapan suatu pendekatan, metode dan teknik pembelajaran. Untuk melaksanakan tugasnya secara profesional, seorang guru dituntut dapat memahami dan memiliki keterampilan yang memadai dalam mengembangkan berbagai model pembelajaran efektif, kreatif dan menyenangkan sebagaimana diisyaratkan dalm kurikulum tingkat satuan pendidikan.
Menurut Deporter, dkk ( Ambar, 2010: 9) menyatakan "Peta pikiran adalah metode mencatat kreatif yang memudahkan mengingat banyak informasi. Sedangkan menurut Suryanto ( Kariau, 2013: 8) “ Mind Mapping adalah cara termudah untuk mendapatkan informasi ke dalam otak dan mengambil informasi keluar dari otak yang merupakan cara mencatat yang kretif dan efektif".

Dari pendapat tersebut dapat disimpulkan bahwa peta pikiran (mind mapping) adalah model pembelajaran yang membantu peserta didik untuk menggali informasi dengan cara mencatat kreatif. Peta pikiran merupakan alat yang membantu otak berpikir secara teratur. Peta pikiran menggunakan warna, memiliki struktur alami yang memancar dari pusat, menggunakan garis lengkung, simbol, kata dan gambar yang sesuai dengan satu rangkaian yang sederhana, mendasar, alami, dan sesuai dengan cara kerja otak. Peta pikiran dapat melihat hubungan antara satu ide dengan ide yang lainnya dengan tetap memahami konteksnya. Peta pikiran sangat memudahkan otak untuk memahami dan menyerap informasi dan juga memudahkan untuk mengembangkan ide karena bisa mulai dengan suatu ide utama dan kemudian menggunakan koneksi-koneksi di otak untuk memecahnya menjadi yang lebih rinci. Peta pikiran menggunakan pengingat-pengingat visual dan sensorik dalam suatu pola dari ide-ide yang berkaitan, seperti peta jalan yang digunakan untuk belajar, mengorganisasikan, dan merencanakan. Peta pikiran dapat membangkitkan ide-ide orisinal dan memicu ingatan yang mudah, ini lebih mudah daripada metode pencatatan tradisional karena mengaktifkan kedua belahan otak.

\section{METODOLOGI}

Penelitian ini akan dilaksanakan pada bulan Maret 2014 hingga Juli 2014, tahun pelajaran 2013/2014. Penelitian ini akan dilaksanakan di MIS Hidayatul Insan Jl. 
Sulawesi No. 67 Palangka Raya. Peneliti mengambil tempat penelitian di MIS ini karena hasil belajar IPA masih rendah. Selain alasan tersebut peneliti juga memilih sekolah ini karena sekolah ini adalah tempat PPL peneliti, sehingga secara sosial sudah ada hubungan dan terjalin komunikasi dengan sekolah ini.

Dalam penelitian ini dilaksanakan dengan menggunakan Penelitian Tindakan Kelas ( PTK ) dengan model pembelajaran peta pikiran (mind mapping). Hal ini dipilih dengan alasan agar proses pembelajaran IPA menjadi menarik dan meningkatkan hasil pembelajaran IPA. Model ini mudah dipahami serta sesuai dengan rencana kegiatan yang akan dilakukan peneliti yaitu satu siklus tindakan identik dengan satu kali pembelajaran.

Menurut Kunandar, (2010:45) menyatakan bahwa "PTK penelitian tindakan yang dilakukan dengan tujuan memperbaiki mutu praktik pembelajaran dikelas".

Sedangkan menurut Kemis dan

Mc. Taggart (Masnur Muslich, 2012:8) "PTK adalah studi yang dilakukan untuk memperbaiki diri sendiri, pengc 23 kerja sendiri, yang dilaksanakan unum sistematis, terencana, dan dengan sikap mawas diri".

Penelitian tindakan kelas termasuk penelitian kualitatif meskipun data yang dikumpulkan bisa saja bersifat kuantitatif , dimana uraiannya bersifat deskriptif dalam bentuk kata-kata, peneliti merupakan instrumen utama dalam pengumpulan data., proses sama pentingnya dengan produk. Perhatian peneliti diarahkan kepada pemahaman bagaimana berlangsungnya suatu kejadian.

Berdasarkan jenis penelitian yang digunakan yaitu PTK (penelitian tindakan kelas), maka kehadiran dan peran peneliti dalam penelitian ini adalah peneliti melakukan kolaboratif dengan pihak lain. Dimana peneliti akan berkolaboratif dengan teman sejawat selaku pihak lain yang yang dijadikan sebagai mitra oleh peneliti. Adapun peran teman sejawat berperan sebagai pengamat. Hal ini diperlukan untuk mendukung objektivitas dari hasil penelitian tindakan kelas yang dilakukan agar penelitian dapat berjalan sesuai dengan tujuan yang diinginkan.

Dalam penelitian ini dilaksanakan menggunakan model Kemmis dan Mc Taggart, pelaksanaan penelitian ini mencakup 4 langkah dalam setiap siklusnya yaitu :

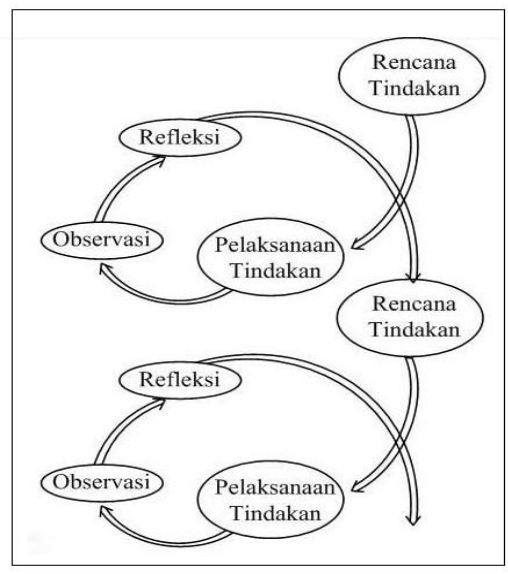

\section{Gambar 1}

Model Kemmis \& Taggart

Observasi bertujuan untuk mengamati kegiatan peserta didik dan guru selama penelitian pada kegiatan pembelajaran yang dilakukan oleh peneliti. Sudjana (2011:84) mengemukakan bahwa observasi atau pengamatan banyak digunakan untuk mengukur tingkah laku individu ataupun proses terjadinya suatu kegiatan yang dapat diamati baik dalam situasi yang sebenarnya maupun dalam situasi buatan. Sedangkan menurut Kusnandar (2008:73) “ observasi dalam PTK adalah kegiatan pengumpulan data yang berupa proses perubahan kinerja SPI". Berdasarkan pendapat para ahli di atas maka dapat disimpulkan bahwa observasi dalam penelitian ini digunakan untuk mengumpulkan data tentang keaktifan bertanya peserta didik dalam proses belajar mengajar.

Data yang dikumpulkan dari setiap kegiatan yang dilaksanakan dalam siklus PTK dianalisis secara deskriptif dengan mengguanakan teknik persentase untuk melihat kecenderungan yang terjadi dalam 
pembelajaran. Data yang diperoleh melalui instrumen yang telah dikumpulkan sebelumnya diolah menjadi dua jenis data yaitu kuantitatif dan kualitatif.

Data kuantitatif digunakan untuk mengetahui jumlah peningkatan hasil belajar yang terjadi pada peserta didik setelah pembelajaran berlangsung. Sedangkan data kualitatif adalah data untuk menerangkan tentang terjadinya pembelajaran. Sehingga pembelajaran dapat dirinci dan diterangkan melalui data kualitatif.

Penelitian ini merupakan penelitian dengan menghubungkan dua metode penelitian yaitu kuantitatif dan kualitatif. Sugiyono (2013:32) menyatakan bahwa:

Johnson dan Cristensen (2007) memberikan definisi tentang metode penelitian kombinasi (mixed recearch) sebagai berikut: Metode penelitian Kombinasi merupakan pendekatan dalam penelitian yang mengkombinasikan atau menghubungan antara metode penelitian kuantitatif dan kualitatif. Hal ini mencakup landasan filosofis. Penggunaan pendekatan kualitatif dan kuantitatif, dan kombinasikan kedua pendekatan dalam penelitian.

Metode penelitian kombinasi adalah suatu metode penelitian kuantitatif dan kualitatif untuk digunakan secara bersama-sama dalam suatu kegiatan penelitian. Sehingga diperoleh data yang lebih komprehensif, valid. Reliabel dan objektif. Dengan menggunakan metode kombinasi maka realibilitas data akan dapat ditingkatkan, karena relibilitas data yang tidak dapat diuji dengan metode kualitatif atau sebaliknya.

Menurut Sudijono (2012:66) "Tes adalah alat atau prosedur yang dipergunakan dalam rangka pengukuran dan penilaian"

Dari pendapat tersebut dapat disimpulkan untuk mendapatkan hasil tanggapan atau respon belajar yang dibutuhkan oleh peneliti, maka peneliti menggunakan tes. Tes dalam penelitian ini menggunakan pretest dan posttest. Dimana pretest (tes kemampuan awal), berfungsi untuk menilai kemampuan awal peserta didik. Sedangkan postest (tes hasil belajar IPA), berfungsi untuk menilai kemampuan peserta didik mengenai penguasaan materi pelajaran setelah pembelajaran diberikan.

\section{HASIL DAN PEMBAHASAN}

Pra tindakan adalah perlakukan awal seorang guru kepada peserta didik sebelum memberikan atau memasuki materi pembelajaran. Dalam melakukan pra tindakan peneliti harus melakukan observasi pra tindakan dan tes pra tindakan yang dapat dijadikan sebagai tolak ukur keberhasilan pembelajaran selanjutnya.

Berdasarkan perhitungan nilai ratarata dan ketuntasan hasil belajar didapat hasil tes awal peserta didik kelas IV Mis Hidayatul Insan Palangka Raya didapat rata-rata sebesar 42,63 dengan ketuntasan belajar sebesar $25 \%$ yang termasuk kedalam kategori sangat kurang tercapai. Nilai rata-rata peserta didik yang sebesar 42,63 masih belum mencapai kriteria ketuntasan minimal yaitu 60 dan nilai ketuntasan belajar sebesar $25 \%$ masih jauh dari kriteria ketuntasan secara klasikal yaitu $85 \%$. Sehingga pada tes awal tingkat ketercapaian keberhasilan pembelajaran masih belum memenuhi syarat ketuntasan belajar.

Melalui pembelajaran menggunakan model pembelajaran peta pikiran ( mind mapping ) oleh peneliti di kelas IV MIS Hidayatul Insan Palangka Raya aktivitas guru dan peserta didik menunjukkan peningkatan yang baik. Pada saat siklus I peserta didik masih belum terbiasa pada pembelajaran dengan model pembelajaran peta pikiran (mind mapping), peserta didik kurang aktif dalam bertanya jawab dan kurang memperhatikan penjelasan pendidik. Namun pada siklus II, aktivitas peserta didik mengalami peningkatan dan dilihat saat pembelajaran berlangsung peserta didik aktif dalam bertanya jawab, memperhatikan penjelasan pendidik, antusias dan semangat pada proses pembelajaran berlangsung, serta 
sangat kretaif dalam membuat peta pikiran (mind mapping).

Hasil belajar yang diperoleh berdasarkan hasil tes pada peserta didik kelas IV di MIS Hidayatul Insan Palangka yang menggunakan model pembelajaran peta pikiran ( mind mapping ) mengalami peningkatan, yaitu 32 orang peserta didik tuntas dalam pembelajaran, namun masih ada 4 peserta didik yang masih belum tuntas, hal ini dikarenakan peserta didik tersebut masih belum memahami beberapa penjelasan pendidik yang mencakup beberapa aspek pembelajaran. Namun secara keseluruhan peserta didik telah melakukan pembelajaran yang sangat baik dan mampu mencapai ketuntasan secara klasikal $88 \%$. Rekapitulasi datanya dapat dilihat sebagai berikut :

Tabel 1

Rekapitulasi Hasil Belajar IPA pada Materi Energi Panas dan Energi Bunyi

\begin{tabular}{|c|l|c|c|c|}
\hline \multirow{2}{*}{ No } & \multirow{2}{*}{ Nama } & \multicolumn{3}{|c|}{ Nilai } \\
\cline { 3 - 5 } & & $\begin{array}{c}\text { Data } \\
\text { Awa } \\
\text { I }\end{array}$ & $\begin{array}{c}\text { Siklu } \\
\text { s I }\end{array}$ & $\begin{array}{c}\text { Siklu } \\
\text { s II }\end{array}$ \\
\hline 1 & AN & 30 & 65 & 70 \\
\hline 2 & AL & 40 & 60 & 70 \\
\hline 3 & AAR & 60 & 75 & 80 \\
\hline 4 & AG & 30 & 60 & 75 \\
\hline 5 & AR & 30 & 55 & 80 \\
\hline 6 & BI & 60 & 70 & 80 \\
\hline 7 & DGS & 35 & 60 & 75 \\
\hline 8 & DI & 40 & 60 & 70 \\
\hline 9 & F & 90 & 90 & 100 \\
\hline 10 & FI & 50 & 60 & 70 \\
\hline 11 & IS & 35 & 60 & 70 \\
\hline 12 & KN & 20 & 60 & 70 \\
\hline 13 & LZ & 20 & 80 & 90 \\
\hline 14 & MA & 45 & 75 & 80 \\
\hline 15 & MN & 20 & 25 & 35 \\
\hline 16 & MW & 55 & 65 & 80 \\
\hline 17 & M & 40 & 50 & 75 \\
\hline 18 & MP & 45 & 80 & 90 \\
\hline 19 & MU & 35 & 50 & 70 \\
\hline 20 & NA & 65 & 75 & 85 \\
\hline 21 & NB & 75 & 80 & 90 \\
\hline
\end{tabular}

\begin{tabular}{|c|c|c|c|c|}
\hline 22 & NAP & 30 & 35 & 70 \\
\hline 23 & PU & 20 & 35 & 45 \\
\hline 24 & PSN & 60 & 65 & 85 \\
\hline 25 & $\mathrm{RH}$ & 40 & 55 & 75 \\
\hline 26 & $\overline{R Y}$ & 45 & 45 & 70 \\
\hline 27 & $\mathrm{RM}$ & 70 & 95 & 100 \\
\hline 28 & SA & 25 & 65 & 70 \\
\hline 29 & SF1 & 45 & 60 & 70 \\
\hline 30 & SF2 & 50 & 50 & 55 \\
\hline 31 & SM & 60 & 70 & 80 \\
\hline 32 & WZ & 40 & 40 & 50 \\
\hline 33 & YU & 30 & 50 & 70 \\
\hline 34 & $\overline{\mathrm{ZN}}$ & 15 & 55 & 75 \\
\hline \multirow[b]{2}{*}{ No } & \multirow[b]{2}{*}{$\begin{array}{c}\text { Nam } \\
\mathbf{a}\end{array}$} & \multicolumn{3}{|c|}{ Nilai } \\
\hline & & $\begin{array}{c}\text { Data } \\
\text { Awa } \\
\text { l }\end{array}$ & $\begin{array}{c}\text { Siklu } \\
\text { S I }\end{array}$ & $\begin{array}{c}\text { Siklu } \\
\text { S II }\end{array}$ \\
\hline 35 & $\overline{\mathrm{ZT}}$ & 25 & 35 & 70 \\
\hline 36 & $\mathrm{ZA}$ & 60 & 75 & 85 \\
\hline \multicolumn{2}{|c|}{ Jumlah } & 1535 & 2185 & 2675 \\
\hline \multicolumn{2}{|c|}{$\begin{array}{l}\text { Rata - } \\
\text { rata }\end{array}$} & $\begin{array}{c}42,6 \\
3\end{array}$ & 60,69 & 74,3 \\
\hline \multicolumn{2}{|c|}{$\begin{array}{l}\text { Ketuntasa } \\
\text { n belajar }\end{array}$} & $25 \%$ & $63 \%$ & $88 \%$ \\
\hline
\end{tabular}

Berdasarkan tabel di atas, dapat dilihat bahwa pada tes awal nilai rata-rata peserta didik hanya memperoleh nilai rata-rata 42,63. Nilai ini masih jauh dari kriteria ketuntasan minimal yang ditentukan yaitu 60. Hasil ketuntasan belajar secara klasikal juga hanya memperoleh nilai sebesar $25 \%$, sedangkan kriteria ketuntasan klasikalnya minimal $85 \%$. Kemudian pada siklus I nilai rata-rata peserta didik mengalami peningkatan sebesar 60,69 meskipun masih belum mencapai kriteria ketuntasan minimal, secara klasikal pun masih belum mencapai $85 \%$, karena nilai yang diperoleh pada siklus I hanya sebesar 63\%. Pada siklus II nilai rata-rata peserta didik mengalami peningkatan cukup bagus dengan perolehan nilai rata-rata 74,3 dengan kriteria ketuntasan secara klasikal mencapai $88 \%$. Peneliti menganggap pada 
siklus II ini sudah berhasil karena telah mencapai nilai ketuntasan secara klasikal.

Berdasarkan hasil penelitian di atas maka pelaksanaan perbaikan aktivitas dan hasil belajar peserta didik pada materi energi panas dan energi bunyi dengan menggunakan model pembelajaran peta pikkiran ( mind mapping ) dapat membantu meningkatkan hasil belajar peserta didik. Indikator yang menunjukkan aktivitas dan hasil belajar peserta didik dalam pembelajaran yang menjadi indikator penilaian pengamatan guru dalam penelitian ini adalah :

1. Aktivitas peserta didik dalam mengikuti pembelajaran indikator pencapaiannya adalah : peserta didik antusias dalam membuat peta pikiran sesuai dengan kreatifitasnya masing-masing.

2. Hasil belajar, indikator pencapaiannya adalah : hasil belajar peserta didik meningkat dan pada proses pembelajaran peserta didik aktif dalam bertanya jawab.

\section{KESIMPULAN}

Berdasarkan data hasil penelitian dan pembahasan dalam penelitian tindakan kelas (PTK) yang didapat peneliti selama penelitian dilakukan di MIS Hidayatul Insan Palangkaraya dikelas IV adalah sebagai berikut :

1. Berdasarkan pengamatan hasil aktivitas peserta didik selama pembelajaran IPA dengan menggunakan model peta pikiran ( mind mapping ) pada siklus I dan II lebih aktif, pada siklus I memperoleh skor rata-rata 3,1 dengan kriteria baik, meningkat menjadi baik pada siklus II dengan skor rata-rata 3,6 dengan kriteria baik. Berdasarkan hasil tersebut dapat disimpulkan bahwa peserta didik merespon terhadap kegiatan pembelajaran yang dilakukan dengan menggunakan model peta pikiran ( mind mapping ).
2. Ada peningkatan hasil belajar peserta didik kelas IV di MIS Hidayatul Insan Palangkaraya dari tes awal memperoleh data presentase $25 \%$. Sedangkan di siklus I ada peningkatan hasil belajar peserta didik memperoleh data presentase $63 \%$ dengan kreteria cukup dominan dari 23 orang peserta didik memperoleh nilai di atas KKM dari 36 orang jumlah peserta didik di kelas IV sedangkan sisa 13 orang peserta didik masih memperoleh nilai<60, sementara pada siklus II mengalami peningkatan dengan ratarata skor presentase $88 \%$ dengan kriteria baik dari 32 orang peserta didik mendapatkan nilai diatas KKM $\geq 60$ sehingga siklus II dinyatakan tuntas dari klasikal yang diharapkan ditempat penelitian diatas $85 \%$.

3. Berdasarkan semua hasil tersebut dapat ditarik kesimpulan bahwa penggunaan model pembelajaran peta pikiran ( mind mapping ) dapat meningkatkan hasil belajar IPA kelas IV di MIS Hidayatul Insan Palangkaraya dalam materi energi panas dan energi bunyi.

Berdasarkan hasil penelitian yang dilakukan pada peserta didik kelas IV di MIS Hidayatul Insan Palangkaraya bahwa dengan menggunakan model pembelajaran peta pikiran ( mind mapping ) dalam pembelajaran IPA materi energi panas dan energi bunyi dapat meningkatkan hasil belajar IPA peserta didik maka disarankan

1. Bagi kepala sekolah diharapkan dapat mendukung dan menyarankan guru-guru agar menggunakan model pembelajaran dan menciptakan pembelajaran yang menyenangkan dalam rangka meningkatkan motivasi belajar peserta didik.

2. Bagi guru sebaiknya dalam pembelajaran IPA dapat menggunakan model pembelajaran 
peta pikiran (mind mapping), agar peserta didik menjadi lebih aktif, kreatif dan bersemangat serta termotivasi untuk belajar. Sebelum menerapkan pembelajaran dengan menggunakan model peta pikiran guru harus menguasai materi pembelajaran yang sudah dipelajari maupun materi yang akan dipelajari sebagai data awal dan mampu mengaitkan materi pembelajaran dengan kehidupan yang nyata.

3. Bagi peserta didik, disarankan agar lebih aktif dan kreatif mampu berfikir secara kritis, logis dengan penerapan model pembelajaran peta pikiran (mind mapping) pada pembelajaran IPA, serta lebih giat belajar agar mendapatkan hasil belajar yang baik.

\section{DAFTAR PUSTAKA}

Djamarah, (2011). Pengertian Belajar dan Hasil

Belajar.http://Duniabaca.com.html. Diakses tanggal 03 Maret 2012

Aqib, Zainal. (2014). Model-model, Media, dan Strategi Pembelajaran Konstekstual (Inovatif). Bandung : Penerbit Yrama Widya.

Hamalik, 2008. Proses Belajar Mengajar. Jakarta: Bumi Aksara.

Iskandar. (2008). Metodologi Penelitian dan Sosial (Kuantitatif dan Kualitatif), Jakarta : Gaung Persada Press.

Kunandar. (2012). Langkah Mudah Penelitian Tindakan Kelas Sebagai Pengembangan Profesi Guru. Jakarta: PT Raja Grafindo Persada.

Kuswantini. (2008). Penerapan Metode Inkuiri untuk Meningkatkan Hasil belajar Siswa Kelas IV SDN

Pusungmalang II Kabupaten Pasuruan. Pasuruan; Kuswantini.
Ngalimun. 2012. Strategi dan Model Pembelajaran. Banjarmasin :Aswaja Pressindo.

Nur Hamiyah \& Muhammad Jauhar. (2014). Strategi belajar mengajar dikelas. Jakarta : Prestasi

Pus takaraya.

Nasikhul, Muhammad. (2013). Makalah Metode Penelitian Kombinasi. (http://muhammadnasikhul.com/201 3/10/makalah-metode-penelitiankombinasi). Diaskes bulan oktober 2013.

Rahmadani, Mawaddah,dkk. (2012). Penerapan Strategi Pembelajaran Inkuiri (SPI) Untuk Meningkatkan Hasil Belajar IPS Siswa Kelas IV Sekolah Dasar Negeri 153 Pekanbaru. Pekanbaru : Rahmadani.

Roestiyah. (2008). Strategi Belajar Mengajar. Jakarta. Rineka Cipta.

Sanjaya, Wina. (2006). Strategi

Pembelajaran Berorientasi Standar

Proses Pendidikan. Jakarta:

Kencana.

Sari, Permata Berlian. (2013). Upaya Meningkatkan Hasil Belajar Matematika dengan Menggunakan Media Papan Berpaku.Palangkaraya :FKIP Universitas Muhammadiyah Palangkaraya.

Suhardjono. (2006). Penelitian Tindakan Kelas Sebagai Kegiatan Pengembangan Profesi Guru. Jakarta: Bumi Aksara.

Suharsimi, A., dkk. (2006). Penelitian Tindakan Kelas. Jakarta : Bumi Aksara.

Suharsimi Arikunto. (2006). Penelitian Tindakan Kelas, Jakarta: PT Bumi Aksara. 
Sukayati. (2008). Penelitian Tindakan

Kelas di SD. Yogyakarta.

Anurrahman, (2009). Belajar dan Pembelajaran.Bandung.Penerbit:CV.Alfab et.

Aunurrahman., (2010). Belajar dan Pembelajaran. Bandung:

Alfabeta.

Darmadi, Hamid (2013). Metode Penelitian Guruan dan Sosial. Bandung:

Alfabeta

Depdiknas, (2003). Undang-Undang Nomor 20 Tahun 2003 Tentang Sistem Pendidikan Nasional. Jakarta: Sekretariat Negara.

Fiati, A., (2010). Penggunaan Strategi Peta Pikiran Pada Materi Pokok Besaran Dan Satuan Pada Siswa Kelas VII Semester I Smp Negeri 3 Palangka Raya Tahun Ajaran 2009/2010. Proposal. Universitas Palangka Raya

Hanifah,S.(2013).Penggunaan Model Mind Map dalam Peningkatan Pembelajaran IPS Siswa Kelas IV SDN 2 Darmakradenan Kecamatan Ajibarang Kabupaten Banyumas Tahun Ajaran 2012/2013. Jurnal Penelitian. Universitas Sebelas Maret

Hyerle,D., \& Alper,L (2012). Peta

Pemikiran. Jakarta : Indeks

Irawaty, Yunifa., (2011). Penerapan Model Pembelajaran Advance Organizer Dengan Bantuan Peta Konsep Pada Materi Pokok Usaha Dan
EnergiDi Kelas XI Semester I Sma Negeri 3 Palangkaraya Tahun Ajaran 2010/2011. Proposal. Universitas Palangka Raya

Kariau, (2013). Penerapan model mind mapping untuk meningkatkan hasil belajar IPA peserta didik kelas IV pada SDN 1 pahandut tahun pelajaran 2012/2013. Skripsi. Universitas Muhammadiyah Palangkaraya

Kunandar, (2010). Langkah Mudah Penelitian Tindakan Kelas. Jakarta : Rajagrafindo Persada.

Mangatur Tua Sijabat., (2013), Upaya Meningkatkan Hasil Belajar IPA Peserta Didik Menggunakan Multimedia Di Kelas VI SDN-1Menteng Palangka Raya. Palangka Raya:Universitas Muhammadiyah Palangka Raya

Muslich, Masnur, (2012). Melaksanakan PTK Itu Mudah, Jakarta : Bumi Aksara.

Sangadji,dkk (2010). Metodologi Penelitian Pendekatan Praktis Dalam Penelitian. Yogyakarta : Andi Offset

Sari, M.J., (2012). Perbedaan Hasil Belajar IPA Antara yang Menggunakan Metode Mind Mapping dengan Metode Demonstrasi Pada Peserta didik Kelas V SDN-6 Panarung Palangka Raya, Proposal. Universitas Muhammadiyah Palangkaraya 
Silberman, M ., (2013). Pembelajaran Aktif 101 Strategi untuk Mengajar Secara Aktif. Jakarta: Indeks

Slameto, (2013). Belajar dan Faktorfaktor Yang Mempengaruhi, Jakarta : PT Rineka Cipta

Slamet Widodo, (2014). Skripsi Upaya meningkatkan Hasil Belajar IPS Dengan Menggunakan Media Wayang Pancasila Pada Peserta didik Kelas V SDN-3 Menteng palangkaraya Tahun pelajaran 2013/ 1014, Skripsi . Universitas Palangkaraya.

Suartini, K., (2011). Perbedaan Hasil Belajar IPA Dilihat dari Penggunaan Media Objek Kelas IV SDN-1 Menteng Palangka Raya, Proposal. Universitas Muhammadiyah Palangkaraya

Sudijono, A., (2012). Pengantar Evaluasi Guruan. Jakarta : Rajagrafindo Persada

Sudjana, N. (2010). Dasar-dasar proses belajar mengajar. Bandung : Sinar Baru Algresindo

Sugiyono, (2011). Metode Penelitian Pendidikan. Bandung: Alfabeta.

Suryabrata, S., (2010). Metodologi Penelitian. Jakarta:Rajagrafindo Persada

Suryanto, Adi dkk, (2008). Evaluasi

Pembelajaran di SD. Jakarta :

Universitas Terbuka 